\title{
Evaluating performance of Two-Step Networks Using Fuzzy Data Envelopment
}

\section{Analysis}

Amir Rahmani

Department of Mathematics, Science and Research Branch, Islamic Azad University, Tehran, Iran. rahmani.amir@yahoo.com.

Mohsen Rostamy-malkhalifeh

Department of Mathematics, Science and Research Branch, Islamic Azad University, Tehran, Iran.. Mohsen_Rostamy@yahoo.com

Farhad Hosseinzadeh Lotfi ${ }^{3}$

Department of Mathematics, Science and Research Branch, Islamic Azad University, Tehran, Iran. farhad@hosseinzadeh.ir.

Editor Científico: José Edson Lara

Organização Comitê Científico

Double Blind Review pelo SEER/OJS

Recebido em 17.08.2019

Aprovado em 25.03.2020

Este trabalho foi licenciado com uma Licença Creative Commons - Atribuição - Não Comercial 3.0 Brasil 


\begin{abstract}
In order to improve the performance of each decision making unit and identify weaknesses and strengths of them, managers frequently need to compare performance of units under their supervision with performance of other existing homogeneous decision making units. Earlier methods in traditional data envelopment analysis investigate efficiency for single stage decision making units with crisp data which use some inputs $\mathrm{X}$ to product final outputs $\mathrm{Y}$. If we envisage multistage decision making units with external inputs, intermediate flows and final outputs which some or all of them are not crisp necessarily, the decision making units can't be easily evaluated. In this paper we promote a new technique based on the composition method to evaluate the efficiency score of two-stage production processes where data are not crisp in specific required model which is unskew and the efficiency scores evaluated by it are unique. The proposed method consider expected interval of fuzzy values and use the convex combination of two end-point of them to measure each stages' efficiency and the overall efficiency score for different $\alpha$-values. We use multiplicative CCR output-oriented and CCR input-oriented fuzzy models for the first and second stages respectively to assess efficiency scores for the two stages, which are then aggregated to get the overall efficiency score of the evaluated unit. In order to evaluate the performance of the method, the efficiencies of four decision making units are calculated which transform two external inputs to an intermediate measure and then use it to product two final outputs which all data are fuzzy value, and thus it is shown how our method leads in exact results.
\end{abstract}

Key Words: Efficiency, Data envelopment analysis, Network DEA, Fuzzy data.

\title{
Avaliando o desempenho de redes em duas etapas usando a Análise de Envelope de Dados Difusos
}

\section{Resumo}

Para melhorar o desempenho de cada unidade de tomada de decisão e identificar pontos fracos e pontos fortes deles, os gerentes frequentemente precisam comparar o desempenho das unidades sob sua supervisão com o desempenho de outras unidades de tomada de decisão homogêneas existentes. Os métodos anteriores na análise tradicional de envelopamento de dados investigam a eficiência de unidades de tomada de decisão de estágio único com dados precisos que usam algumas entradas $\mathrm{X}$ para as saídas finais do produto Y. Se projetarmos unidades de tomada de decisão de vários estágios com entradas externas, fluxos intermediários e saídas finais que alguns ou todos os eles não são necessariamente precisos, as unidades de tomada de decisão não podem ser facilmente avaliadas. Neste artigo, promovemos uma nova técnica baseada no método de composição para avaliar o escore de eficiência de processos de produção em dois estágios, onde os dados não são nítidos no modelo requerido específico, que é desconhecido e os escores de eficiência avaliados por ele são únicos. O método proposto considera o intervalo esperado de valores nebulosos e usa a combinação convexa de dois pontos finais deles para medir a eficiência de cada estágio e a pontuação geral de eficiência para diferentes valores $\alpha$. Usamos modelos difusos orientados para a saída CCR e voltados para 
entrada CCR multiplicativos, respectivamente, para o primeiro e o segundo estágio, respectivamente, para avaliar os escores de eficiência dos dois estágios, que são agregados para obter o escore geral de eficiência da unidade avaliada. Para avaliar o desempenho do método, são calculadas as eficiências de quatro unidades de tomada de decisão que transformam duas entradas externas em uma medida intermediária e, em seguida, as utilizam para produzir duas saídas finais com todos os dados com valor difuso e, portanto, é mostrado como nosso método leva a resultados exatos.

Palavras-chaves: Eficiência, análise de envelopamento de dados, DEA da rede, dados difusos.

\section{Introduction}

Data envelopment analysis was first introduced by Charns, Cooper and Rhodes (CCR), [3] under the assumption of constant return to scale is an efficient technique for evaluating the performance of a set of decision-making units with crisp data that was later developed by Banker et al (BCC), [1] under the assumption of variable return to scale.

In Classical DEA models, DMUs are treated as single-stage production structures which all inputs and outputs are fully specific data. So Two questions arise for us. (1) How should we evaluate the performance of multistage structures? (2) What should we do when the measures are not crisp data. Fortunately, these two questions have been the subject of many studies.

Today, the performance evaluation of multi-stage production-structures has received considerable attention from a large number of studies where external inputs or other stage's outputs cab be used as each stage's inputs [4-5, 10]. Lately, Despotis and Koronakos focused on the two-stage production-structures and represented their method that is called "the composition approach".

Likewise, in the real world data for evaluation is not crisp and are stated by natural language such as Cold, cool, temperate or warm to recitation general situation. Therefore, some different fuzzy models are provided to evaluate single and recently multistage DMUs with fuzzy data, based on the concept of comparison of fuzzy numbers that drive the overall efficiency of the system [2, 6-8, 12-13]. Some of these methods such as those based on Kao and Hwang [11] and Chen et al [4] by driving and measuring the weights endogenously either may give precedence to one stage over the other or may not results in unique measures for the efficiency of the individual stages.

In this paper a new technique will be introduced to evaluate the performance and compute overall efficiency score of two-stage production-structures where data are not crisp in specific required model based on "the composition approach" which is un-skew and the efficiency 
scores evaluated by it are unique. Multiplicative CCR output-oriented and CCR input-oriented fuzzy models will be used for the first and second stages respectively to appraisal efficiency scores for each stage separately, which are then aggregated to get the overall efficiency score of the evaluated unit.

\section{The composition approach}

Consider a set of $n$ DMUs which any $\operatorname{DMU}_{j}(j=1, \ldots, n)$ includes a two-stage production structure such that $\mathrm{t}$ intermediate values $\mathrm{z}_{\mathrm{qj}}(\mathrm{q}=1, \ldots, \mathrm{t})$ in which are produced by some of external inputs $x_{i j}(i=1, \ldots, m)$ in the first stage will transformed to final outputs $y_{r j}(r=$ $1, \ldots, s)$ in second stage as depicted in figure 1 .

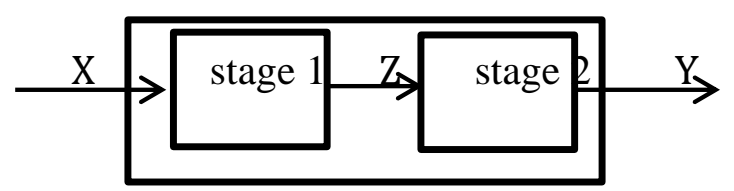

Figure 1: A Tow-Stage Production Procces

We use the following basic symbolization throughout the article (Figure 2)

\begin{tabular}{|c|c|}
\hline Notation & \\
\hline $\mathrm{j} \in \mathrm{J}=\{1, \ldots, \mathrm{n}\}$ & The index set of the $n$ DMUs \\
\hline $\mathrm{j}_{\mathrm{p}} \in \mathrm{J}$ & Denote the evaluated DMU \\
\hline $\mathrm{X}_{\mathrm{j}}$ & The vector of external inputs used by $\mathrm{DMU}_{\mathrm{j}}, \mathrm{j} \in \mathrm{J}$ \\
\hline $\mathrm{Z}_{\mathrm{j}}$ & The vector of intermediate flows for $\mathrm{DMU}_{\mathrm{j}}, \mathrm{j} \in \mathrm{J}$ \\
\hline$Y_{j}$ & The vector of final outputs produced by $\mathrm{DMU}_{\mathrm{j}}, \mathrm{j} \in \mathrm{J}$ \\
\hline V & The vector of variable weights associated with the external inputs \\
\hline W & The vector of variable weights associated with the intermediate flows \\
\hline $\mathrm{U}$ & The vector of variable weights associated with the final outputs \\
\hline$e_{j}^{p}$ & The overall efficiency of $\mathrm{DMU}_{\mathrm{j}}, \mathrm{j} \in \mathrm{J}$ \\
\hline$e_{j}^{1}$ & The efficiency of the first stage for $\mathrm{DMU}_{\mathrm{j}}, \mathrm{j} \in \mathrm{J}$ \\
\hline$e_{j}^{2}$ & The efficiency of the second stage for $\mathrm{DMU}_{\mathrm{j}}, \mathrm{j} \in \mathrm{J}$ \\
\hline
\end{tabular}

Figure 2: Basic symbolization

Consider two models CCR output-oriented for the first stage and CCR input-oriented for the second stage, which are presented in the following:

$$
\mathrm{e}_{\mathrm{p}}^{1}: \min \mathrm{VX}_{\mathrm{p}}
$$

s.t. $\quad W Z_{p}=1$

$$
\begin{aligned}
& \mathrm{WZ}_{\mathrm{j}}-\mathrm{VX}_{\mathrm{j}} \leq 0 \quad, \quad \mathrm{j}=1, \ldots, \mathrm{n} \\
& \mathrm{V} \geq \mathbf{0}, \mathrm{W} \geq \mathbf{0}
\end{aligned}
$$




$$
\begin{array}{ll} 
& \mathrm{e}_{\mathrm{p}}^{2}: \quad \max U Y_{\mathrm{p}} \\
\text { s.t. } \quad \mathrm{WZ}_{\mathrm{p}}=1 \\
\\
\quad U Y_{j}-W Z_{j} \leq 0 \quad, \quad j=1, \ldots, \mathrm{n} \\
\mathrm{W} \geq \mathbf{0}, \quad \mathrm{U} \geq \mathbf{0}
\end{array}
$$

By unifying the constraint of two models above and then aggregating the two objective functions, we get the following linear program:

$$
\min \mathrm{VX}_{\mathrm{p}}-\mathrm{UY}_{\mathrm{p}}
$$

$$
\begin{array}{ll}
\text { s.t. } & W Z_{p}=1 \\
U Y_{j}-W Z_{j} \leq 0 \quad, \quad j=1, \ldots, n \\
W Z_{j}-V X_{j} \leq 0 \quad, \quad j=1, \ldots, n \\
V \geq 0, \quad W \geq 0, \quad U \geq 0
\end{array}
$$

If $\left(\mathrm{V}^{*}, \mathrm{~W}^{*}, \mathrm{U}^{*}\right)$ be an optimal solution of model (3) then we will have:

$$
\mathrm{e}_{\mathrm{p}}^{1 *}=\frac{1}{\mathrm{~V}^{*} \mathrm{X}_{\mathrm{p}}} \quad, \quad \mathrm{e}_{\mathrm{p}}^{2 *}=\mathrm{U}^{*} \mathrm{Y}_{\mathrm{p}}
$$

Where the efficiency scores for unit $\mathrm{p}$ in the first and second stage are represented by $\mathrm{e}_{\mathrm{p}}^{1 *}$ and $\mathrm{e}_{\mathrm{p}}^{2 *}$ respectively. After computing the individual efficiency scores, the aggregation of them can be gotten as:

$$
\mathrm{e}_{\mathrm{p}}^{*}=\mathrm{e}_{\mathrm{p}}^{1 *} \cdot \mathrm{e}_{\mathrm{p}}^{2 *}=\frac{\mathrm{U}^{*} \mathrm{Y}_{\mathrm{p}}}{\mathrm{V}^{*} \mathrm{X}_{\mathrm{p}}}
$$

\section{Fuzzy Peleriminaries}

A fuzzy number is a fuzzy set like $\widetilde{X}: R \rightarrow[0,1]$ whose membership function $\mu_{\widetilde{X}}($.$) is upper$ semi continuous and such that for trapezoidal fuzzy number we have:

$$
\mu_{\widetilde{x}}(x)=\left\{\begin{array}{lc}
\frac{x-1}{a-1} & , 1 \leq x \leq a \\
1 & , a \leq x \leq b \\
\frac{u-x}{u-b} & , b \leq x \leq u \\
0 & , \text { otherwise }
\end{array}\right.
$$

The $\alpha$ - cut of a fuzzy number $\widetilde{\mathrm{X}}$ is defined as $\widetilde{\mathrm{X}}_{\alpha}=\left\{\mathrm{x} \mid \mu_{\widetilde{\mathrm{X}}}(\mathrm{x}) \geq \alpha\right\}$ and any $\alpha-$ cut set is represented by $\widetilde{\mathrm{X}}_{\alpha}=\left[\underline{\widetilde{\mathrm{X}}_{\alpha}}, \overline{\widetilde{\mathrm{X}}_{\alpha}}\right]$ which $\underline{\widetilde{\mathrm{X}}_{\alpha}}$ and $\widetilde{\mathrm{X}}_{\alpha}$ are the lower and upper end points of $\alpha-$ cut respectively. Furthermore, the set of all numbers that belongs the universal set R such that $\mu_{\widetilde{\mathrm{X}}}(\mathrm{x})>0$ is known as the supporter set of the fuzzy number $\widetilde{\mathrm{X}}$. 
Based on Heilpern [9], the expected interval and expected value of a fuzzy number $\widetilde{\mathrm{X}}$ are noted by $\operatorname{EI}(\widetilde{\mathrm{X}})$ and $\operatorname{EV}(\widetilde{\mathrm{X}})$ respectively and are defined for trapezoidal fuzzy numbers as follows:

$$
\begin{aligned}
& \operatorname{EI}(\widetilde{X})=\left[E_{1}^{X}, E_{2}^{X}\right]=\left[\int_{0}^{1}(x(a-l)+l) d x, \int_{0}^{1}(u-x(u-b)) d x\right]=\left[\frac{1+a}{2}, \frac{b+u}{2}\right] \\
& \operatorname{EV}(\widetilde{X})=\frac{E_{1}^{X}+E_{2}^{X}}{2}=\frac{1+a+b+u}{4}
\end{aligned}
$$

Proposition1. If $\widetilde{X}$ and $\widetilde{Y}$ are two fuzzy numbers then:

$$
\begin{aligned}
& \operatorname{EI}(\alpha \widetilde{\mathrm{X}}+\beta \widetilde{\mathrm{Y}})=\alpha \operatorname{EI}(\widetilde{\mathrm{X}})+\beta \operatorname{EI}(\widetilde{\mathrm{Y}}) \\
& \quad \operatorname{EV}(\alpha \widetilde{\mathrm{X}}+\beta \widetilde{\mathrm{Y}})=\alpha \operatorname{EV}(\widetilde{\mathrm{X}})+\beta \operatorname{EV}(\widetilde{\mathrm{Y}}) .
\end{aligned}
$$

\section{Efficiency in two-stage network DEA using fuzzy data}

In the real world, we often encounter with multistage processes with data which are not known; because it emphasizes the necessity of assessing efficiency with data which are not crisps, we continue the steps of using mentioned model with fuzzy data.

Consider the expanse form of modified model (3) in the following part for the two-stage processes which external inputs $\tilde{\mathrm{x}}_{\mathrm{ij}}$, intermediate flows $\tilde{\mathrm{z}}_{\mathrm{qj}}$ and final outputs $\tilde{\mathrm{y}}_{\mathrm{rj}}$ are nonnegative fuzzy numbers.

$$
\begin{aligned}
& \min \sum_{\mathrm{i}=1}^{\mathrm{m}} \mathrm{v}_{\mathrm{i}} \tilde{\mathrm{x}}_{\mathrm{ip}}-\sum_{\mathrm{r}=1}^{\mathrm{s}} \mathrm{u}_{\mathrm{r}} \tilde{\mathrm{y}}_{\mathrm{rp}} \\
& \text { s.t. } \sum_{\mathrm{q}=1}^{\mathrm{t}} \mathrm{w}_{\mathrm{q}} \tilde{\mathrm{z}}_{\mathrm{qp}}=1 \\
& \sum_{r=1}^{s} u_{r} \tilde{y}_{r j}-\sum_{q=1}^{t} w_{q} \tilde{z}_{q j} \leq 0 \quad, \quad j=1, \ldots, n \\
& \sum_{\mathrm{q}=1}^{\mathrm{t}} \mathrm{w}_{\mathrm{q}} \tilde{\mathrm{z}}_{\mathrm{qj}}-\sum_{\mathrm{i}=1}^{\mathrm{m}} \mathrm{v}_{\mathrm{i}} \tilde{\mathrm{x}}_{\mathrm{ij}} \leq 0 \quad, \quad \mathrm{j}=1, \ldots, \mathrm{n} \\
& \mathrm{v}_{\mathrm{i}} \geq 0 \quad, \quad \mathrm{i}=1, \ldots, \mathrm{m} \\
& \mathrm{w}_{\mathrm{q}} \geq 0 \quad, \quad \mathrm{q}=1, \ldots, \mathrm{t} \\
& \mathrm{u}_{\mathrm{r}} \geq 0 \quad, \quad \mathrm{r}=1, \ldots, \mathrm{s}
\end{aligned}
$$

If $\left(\mathrm{v}_{1}^{*}, \ldots, \mathrm{v}_{\mathrm{m}}^{*}, \mathrm{w}_{1}^{*}, \ldots, \mathrm{w}_{\mathrm{t}}^{*}, \mathrm{u}_{1}^{*}, \ldots, \mathrm{u}_{\mathrm{s}}^{*}\right)$ be an optimal solution of model (12), the stages efficiencies and the overall efficiency are calculated as follows: 


$$
\mathrm{e}_{\mathrm{p}}^{1 *}=\frac{1}{\sum_{\mathrm{i}=1}^{\mathrm{m}} \mathrm{v}_{\mathrm{i}}^{*} \tilde{\mathrm{x}}_{\mathrm{ip}}} \quad, \quad \mathrm{e}_{\mathrm{p}}^{2 *}=\sum_{\mathrm{r}=1}^{\mathrm{s}} \mathrm{u}_{\mathrm{r}}^{*} \tilde{\mathrm{y}}_{\mathrm{rp}} \quad, \quad \mathrm{e}_{\mathrm{p}}^{*}=\frac{\sum_{\mathrm{r}=1}^{\mathrm{s}} \mathrm{u}_{\mathrm{r}}^{*} \tilde{\mathrm{y}}_{\mathrm{rp}}}{\sum_{\mathrm{i}=1}^{\mathrm{m}} \mathrm{v}_{\mathrm{i}}^{*} \tilde{\mathrm{x}}_{\mathrm{ip}}}
$$

Definition1. Jimenez [10], for any pair of fuzzy numbers $\widetilde{X}$ and $\widetilde{Y}$ the degree in $\widetilde{X}$ bigger than $\widetilde{Y}$ is the following:

$$
\mu_{M}(\widetilde{X}, \widetilde{Y})=\left\{\begin{array}{cc}
0 & \text { if } E_{2}^{\widetilde{X}}<E_{1}^{\widetilde{Y}} \\
\frac{E_{2}^{\widetilde{X}}-E_{1}^{\widetilde{Y}}}{E_{2}^{\widetilde{X}}-E_{1}^{\widetilde{X}}+E_{2}^{\widetilde{Y}}-E_{1}^{\widetilde{Y}}} & \text { if } 0 \in\left[E_{1}^{\widetilde{X}}-E_{2}^{\widetilde{Y}}, E_{2}^{\widetilde{X}}-E_{1}^{\widetilde{Y}}\right] \\
1 & \text { if } E_{2}^{\widetilde{Y}}<E_{1}^{\widetilde{X}}
\end{array}\right.
$$

Where $\left[E_{1}^{\widetilde{X}}, E_{2}^{\widetilde{X}}\right]$ and $\left[E_{1}^{\widetilde{Y}}, E_{2}^{\widetilde{Y}}\right]$ are the expected intervals of $\widetilde{X}$ and $\widetilde{Y}$. When $\mu_{M}(\widetilde{X}, \widetilde{Y}) \geq \alpha$ we will say that $\widetilde{X}$ is bigger than, or equal to $\widetilde{Y}$ at least in degree $\alpha$ and we will represent it by $\widetilde{\mathrm{X}} \geq_{\alpha} \widetilde{\mathrm{Y}}$.

Based on definition1 we can rewrite model (10) and relations (11) as follows:

$$
\begin{aligned}
& \min \sum_{i=1}^{m} v_{i}\left((1-\alpha) E_{1}^{x_{i p}}+\alpha E_{2}^{x_{i p}}\right)-\sum_{r=1}^{s} u_{r}\left((1-\alpha) E_{1}^{y_{r p}}+\alpha E_{2}^{y_{r p}}\right) \\
& \text { s.t. } \sum_{q=1}^{t} w_{q}\left((1-\alpha) E_{1}^{z_{q p}}+\alpha E_{2}^{z_{q p}}\right)=1 \\
& \quad \sum_{r=1}^{s} u_{r}\left((1-\alpha) E_{1}^{y_{r j}}+\alpha E_{2}^{y_{r j}}\right)-\sum_{q=1}^{t} w_{q}\left((1-\alpha) E_{1}^{z_{q j}}+\alpha E_{2}^{z_{q j}}\right) \leq 0, j=1, \ldots, n \\
& \quad \sum_{q=1}^{t} w_{q}\left((1-\alpha) E_{1}^{z_{q j}}+\alpha E_{2}^{z_{q j}}\right)-\sum_{i=1}^{m} v_{i}\left((1-\alpha) E_{1}^{x_{i p}}+\alpha E_{2}^{x_{i p}}\right) \leq 0, j=1, \ldots, n \\
& v_{i} \geq 0 \quad, \quad i=1, \ldots, m \\
& w_{q} \geq 0 \quad, \quad r=1, \ldots, s \\
& u_{r} \geq 0 \quad, \quad j=1, t
\end{aligned}
$$

Model (13) is a crisp $\alpha$-parametric model based on the convex combination of expected interval of fuzzy data.

\section{Numerical example: the findings}

In this section, we represent a simple numerical example with fuzzy two-external input, single-intermediate flow and two-final output. We will consider for DMUs A, B, C and D with their data listed in table1. 
Tab.1: Fuzzy data of two-stage DMUs in numerical example

\begin{tabular}{|l|c|c|c|c|}
\hline \multicolumn{1}{|c|}{ DMU } & A & B & C & D \\
\hline The first external input & $(10,15,15)$ & $(5,8,12,23)$ & $(2,4,10)$ & $(1,6,10,19)$ \\
\hline The second external input & $(5,10,15)$ & $(10,12,18,20)$ & $(3,4,13)$ & $(12,20,28,40)$ \\
\hline Intermediate flow & $(10,15,25)$ & $(12,13,25,40)$ & $(4,5,8,15)$ & $(18,22,40)$ \\
\hline The first final output & $(10,30,30)$ & $(10,15,35,40)$ & $(18,24,38)$ & $(10,15,35,40)$ \\
\hline The second final output & $(15,35,50)$ & $(25,25,35,55)$ & $(22,40,58)$ & $(40,60,80,100)$ \\
\hline
\end{tabular}

Source: own

These DMUs are evaluated by model (13) for different $\alpha$-values in the interval [0,1], using step size 0.1 . The $\alpha$-parametric model to measure both the efficiency score of stages and overall efficiency of DMUs is as follow:

$$
\begin{aligned}
& \min (2.5 \alpha+12.5) \mathrm{v}_{1}+(5 \alpha+7.5) \mathrm{v}_{2}-(10 \alpha+20) \mathrm{u}_{1}-(17.5 \alpha+25) \mathrm{u}_{2} \\
& =1 \\
& (10 \alpha+20) \mathrm{u}_{1}+(17.5 \alpha+25) \mathrm{u}_{2}-(7.5 \alpha+12.5) \mathrm{w} \leq 0 \\
& (25 \alpha+12.5) \mathrm{u}_{1}+(20 \alpha+25) \mathrm{u}_{2}-(20 \alpha+12.5) \mathrm{w} \leq 0 \\
& (10 \alpha+21) \mathrm{u}_{1}+(10 \alpha+31) \mathrm{u}_{2}-(7 \alpha+4.5) \mathrm{w} \leq 0 \\
& (15 \alpha+12.5) \mathrm{u}_{1}+(40 \alpha+50) \mathrm{u}_{2}-(11 \alpha+20) \mathrm{w} \leq 0 \\
& (7.5 \alpha+12.5) \mathrm{w}-(2.5 \alpha+12.5) \mathrm{v}_{1}-(5 \alpha+7.5) \mathrm{v}_{2} \leq 0 \\
& (20 \alpha+12.5) \mathrm{w}-(11 \alpha+6.5) \mathrm{v}_{1}-(8 \alpha+11) \mathrm{v}_{2} \leq 0 \\
& (7 \alpha+4.5) \mathrm{w}-(4 \alpha+3) \mathrm{v}_{1}-(5 \alpha+3.5) \mathrm{v}_{2} \leq 0 \\
& (11 \alpha+20) \mathrm{w}-(11 \alpha+3.5) \mathrm{v}_{1}-(18 \alpha+16) \mathrm{v}_{2} \leq 0 \\
& \mathrm{v}_{1}, \quad \mathrm{v}_{2}, \quad \mathrm{w}, \quad \mathrm{u}_{1}, \quad \mathrm{u}_{2} \geq 0
\end{aligned}
$$$$
\text { s.t. }(7.5 \alpha+12.5) w
$$

The $\alpha$-parametric model for other DMUs can be shown similarity. The results are shown in table 2 for $=0.0,0.1, \ldots, 1.0$. Notice that for any DMU the value of the efficiency score of stages and overall efficiency when $\alpha=0.5$ are the nearest values or exactly equal to the efficiencies derived of expected values.

\section{Conclusions}


In this article a new method for measuring the individual and overall efficiencies in twostage fuzzy DEA based on the composition approach is introduced. The composition method for crisp data has been introduced by Despotis and Koronakos[5]. They reviewed the additive method and the multiplicative method which didn't produce a unique efficiency score for individual stages or gave precedence to one stage over the other. Hence, they proposed the composition method that evaluated the overall efficiency of the system based on the aggregate of efficiency of individual stages in which both the before mentioned issue are resolved. In this paper we utilized an interactive method and saw that the efficiency scores were derived when $\alpha=0.5$ is nearest to the results derived of expected values of fuzzy data. Further researches may involve the development and expansion of our proposed method for multistage systems as well as parallel processes.

\begin{tabular}{|c|c|c|c|c|c|c|c|c|c|c|c|c|}
\hline \multirow{2}{*}{$\begin{array}{r}\alpha \\
\text { value }\end{array}$} & \multicolumn{3}{|c|}{ DMU A } & \multicolumn{3}{|c|}{ DMU B } & \multicolumn{3}{|c|}{ DMU C } & \multicolumn{3}{|c|}{ DMU D } \\
\hline & $\mathrm{e}^{1 *}$ & $\mathrm{e}^{2 *}$ & $\mathrm{e}^{*}$ & $\mathrm{e}^{1 *}$ & $\mathrm{e}^{2 *}$ & $\mathrm{e}^{*}$ & $\mathrm{e}^{1 *}$ & $\mathrm{e}^{2 *}$ & $\mathrm{e}^{*}$ & $\mathrm{e}^{1 *}$ & $\mathrm{e}^{2 *}$ & $\mathrm{e}^{*}$ \\
\hline $\begin{array}{l}\alpha \\
=0.0\end{array}$ & 1 & $\begin{array}{r}0 . \\
34 \\
\end{array}$ & $\begin{array}{r}0 . \\
34 \\
\end{array}$ & $\begin{array}{r}0 . \\
84^{\circ} \\
\end{array}$ & $\begin{array}{r}0 . \\
29 \\
\end{array}$ & $\begin{array}{r}0 . \\
24 \\
\end{array}$ & $\begin{array}{r}0 . \\
89 \\
\end{array}$ & 1 & $\begin{array}{l}0 . \\
89 \\
\end{array}$ & 1 & $\begin{array}{r}0 . \\
36 \\
\end{array}$ & $\begin{array}{l}0 . \\
36 \\
\end{array}$ \\
\hline $\begin{array}{l}\alpha \\
=0.1\end{array}$ & 1 & $\begin{array}{c}0 . \\
37\end{array}$ & $\begin{array}{c}0 . \\
37 \\
\end{array}$ & $\begin{array}{l}0 . \\
93^{2}\end{array}$ & $\begin{array}{c}0 . \\
30\end{array}$ & $\begin{array}{c}0 . \\
28 \\
\end{array}$ & $\begin{array}{r}0 . \\
93 \\
\end{array}$ & 1 & $\begin{array}{r}0 . \\
93 \\
\end{array}$ & 1 & $\begin{array}{c}0 . \\
42\end{array}$ & $\begin{array}{l}0 . \\
42\end{array}$ \\
\hline $\begin{array}{l}\alpha \\
=0.2\end{array}$ & 1 & $\begin{array}{c}0 . \\
40\end{array}$ & $\begin{array}{c}0 . \\
40\end{array}$ & 1 & $\begin{array}{c}0 . \\
31\end{array}$ & $\begin{array}{c}0 . \\
31\end{array}$ & $\begin{array}{r}0 . \\
95^{\circ}\end{array}$ & 1 & $\begin{array}{l}0 . \\
95^{\circ}\end{array}$ & 1 & $\begin{array}{c}0 . \\
47\end{array}$ & $\begin{array}{r}0 . \\
47\end{array}$ \\
\hline $\begin{array}{l}\alpha \\
=0.3\end{array}$ & 1 & $\begin{array}{r}0 . \\
43 \\
\end{array}$ & $43^{0 .}$ & 1 & $\begin{array}{l}0 . \\
33\end{array}$ & $\begin{array}{l}0 . \\
33 \\
\end{array}$ & $\begin{array}{l}0 . \\
93 \\
\end{array}$ & 1 & $\begin{array}{r}0 . \\
93 \\
\end{array}$ & 1 & $\begin{array}{c}0 . \\
52 \\
\end{array}$ & $\begin{array}{c}0 . \\
52 \\
\end{array}$ \\
\hline $\begin{array}{l}\alpha \\
=0.4\end{array}$ & 1 & $\begin{array}{c}0 . \\
45\end{array}$ & $\begin{array}{l}0 . \\
45\end{array}$ & 1 & $\begin{array}{l}0 . \\
34\end{array}$ & $\begin{array}{l}0 . \\
34\end{array}$ & $\begin{array}{c}0 . \\
90\end{array}$ & 1 & $\begin{array}{c}0 . \\
90\end{array}$ & 1 & $\begin{array}{c}0 . \\
56\end{array}$ & $\begin{array}{c}0 . \\
56\end{array}$ \\
\hline $\begin{array}{l}\alpha \\
=0.5\end{array}$ & 1 & $\begin{array}{c}0 . \\
47\end{array}$ & $\begin{array}{r}0 . \\
47\end{array}$ & 1 & $35^{0 .}$ & $\begin{array}{l}0 . \\
35^{\circ}\end{array}$ & $\begin{array}{c}0 . \\
88^{0}\end{array}$ & 1 & $\begin{array}{c}0 . \\
88^{\circ}\end{array}$ & 1 & $\begin{array}{l}0 . \\
61\end{array}$ & $\begin{array}{r}0 . \\
61\end{array}$ \\
\hline $\begin{array}{l}\alpha \\
=0.6\end{array}$ & 1 & $\begin{array}{c}0 . \\
49\end{array}$ & $\begin{array}{l}0 . \\
49\end{array}$ & 1 & $\begin{array}{l}0 . \\
36\end{array}$ & $\begin{array}{l}0 . \\
36\end{array}$ & $\begin{array}{c}0 . \\
86\end{array}$ & 1 & $\begin{array}{l}0 . \\
86\end{array}$ & 1 & $\begin{array}{c}0 . \\
65\end{array}$ & $\begin{array}{c}0 . \\
65\end{array}$ \\
\hline $\begin{array}{l}\alpha \\
=0.7\end{array}$ & 1 & $\begin{array}{c}0 . \\
52\end{array}$ & $\begin{array}{c}0 . \\
52\end{array}$ & 1 & $\begin{array}{l}0 . \\
36\end{array}$ & $\begin{array}{l}0 . \\
36\end{array}$ & $\begin{array}{l}0 . \\
86 \\
\end{array}$ & 1 & $\begin{array}{r}0 . \\
86\end{array}$ & 1 & $\begin{array}{c}0 . \\
70\end{array}$ & $\begin{array}{c}0 . \\
70\end{array}$ \\
\hline $\begin{array}{l}\alpha \\
=0.8\end{array}$ & $\begin{array}{c}0 . \\
98\end{array}$ & $\begin{array}{c}0 . \\
55\end{array}$ & $\begin{array}{c}0 . \\
54\end{array}$ & 1 & $\begin{array}{c}0 . \\
37\end{array}$ & $\begin{array}{c}0 . \\
37\end{array}$ & $\begin{array}{c}0 . \\
86\end{array}$ & 1 & $\begin{array}{c}0 . \\
86\end{array}$ & 1 & $\begin{array}{c}0 . \\
74\end{array}$ & $\begin{array}{c}0 . \\
74\end{array}$ \\
\hline $\begin{array}{l}\alpha \\
=0.9\end{array}$ & $\begin{array}{c}0 . \\
96\end{array}$ & $\begin{array}{c}0 . \\
57\end{array}$ & $\begin{array}{c}0 . \\
55\end{array}$ & 1 & $\begin{array}{c}0 . \\
38\end{array}$ & $\begin{array}{c}0 . \\
38\end{array}$ & $\begin{array}{r}0 . \\
87\end{array}$ & 1 & $\begin{array}{r}0 . \\
87\end{array}$ & 1 & $\begin{array}{c}0 . \\
78\end{array}$ & $\begin{array}{c}0 . \\
78\end{array}$ \\
\hline $\begin{array}{l}\alpha \\
=1.0\end{array}$ & $\begin{array}{r}0 . \\
93^{2}\end{array}$ & $\begin{array}{c}0 . \\
60\end{array}$ & $\begin{array}{c}0 . \\
56\end{array}$ & 1 & $\begin{array}{c}0 . \\
39 \\
\end{array}$ & $\begin{array}{c}0 . \\
39 \\
\end{array}$ & $\begin{array}{r}0 . \\
87 \\
\end{array}$ & 1 & $\begin{array}{r}0 . \\
87\end{array}$ & 1 & $\begin{array}{c}0 . \\
81\end{array}$ & $\begin{array}{r}0 . \\
81\end{array}$ \\
\hline
\end{tabular}

Table 2: The result of $\alpha$-parametric model for all DMUs 


\section{References}

Banker, R. D; Charnes, A. \& Cooper, W.W. (1984). Some models for estimating technical and scale inefficiencies in data envelopment analyses.Manage Sci, 30, 1078-1092.

Bellman, R. E. \& Zadeh, L. A. (1970). Decision-making in a fuzzy environment.Management Sci, 17, 141-164.

Charnes, A.; Cooper, W.W.; \& Rhodes, E. (1978). Measuring the efficiency of decision making units. Eur J Oper Res, 2, 429-444.

Chen, Y.; Cook, W. D.; N. Li, N. \& Zhu, J. (2009). Additive efficiency decomposition in two-stage DEA.Eur J Oper Res, 196, 1170-1176.

Despotis, D. K. \& Koronakos, G. (2014). Efficiency assessment in two-stage processes: A novel network DEA approach.Procedia Computer Science, 31, 299-307.

Grzegorewski, P.; \& Mrwka, E (2005). Trapezoidal approximation of fuzzy number.Fuzzy Sets and Systems, 153, 115-135.

Guo, P. \& Tanaka, H (2001). Fuzzy DEA: a perceptual, evaluation method.Fuzzy Sets and Systems, 119, 149-160.

Rahmani, A. F.; Hosseinzadeh Lotfi, H.; \& Rostamy-Malkhalifeh, M.; T. Allahviranloo, T. (2016). A New Method for Defuzification and Ranking of Fuzzy Numbers Based on the Statistical Beta Distribution.Advances in Fuzzy Systems, 1-8.

Heilpern. S. (1996). The expected valued of a fuzzy number.Fuzzy Sets and Systems, 47, 8186.

Jimenez, M. (2004). Ranking fuzzy numbers through the comparison of its expected intervals. International Journal Of Uncertainty, Fuzziness and Knowledge-Based Systems, 4, 379-388.

Kao, C. \& Hwang, S. N. (2008). Efficiency decomposition in two-stage data envelopment analyses: An application to non-life insurance companies in Taiwan.Eur J Oper Res, $185,418-429$.

Lozano, S. (2014). Process efficiency of two-stage system with fuzzy data. Fuzzy Sets and Systems, 243, 36-49.

Sanei M, M.; Rostamy-Malkhalifeh, \& H.Saleh, H. (2009).A new method for solving fuzzy DEA models. Int. J. Industrial Mathematics, 1(4), 307-313. 